\title{
Functional Orientation and Approach of Cross-Border Electronic Public Services Platform in ASEAN-China Free Trade Area
}

\author{
Li Chongzhao ${ }^{1 *}$ Yu Yimin ${ }^{2}$ Liu Xinping ${ }^{3}$ \\ ${ }^{1}$ School of Public Management, Yunnan University of Finance and Economics, P.R.China, \\ 650221(ㅁanan3721@gmail.com)
}

\begin{abstract}
This research tries to form the function and approach of establishing efficient and convenient Cross-Border Electronic Public Services platform (CBEPSP) in ACFTA. By integrating information release, data search, business management, e-payment and other functions, construction portal website and basic database, reengineering business process support functions application effectively. Together with the legal rules, credit system, coordination mechanism, information security, data exchange standards and norms, ensuring the function securityand effective operation, the availability of CBEPSP will be increased.
\end{abstract}

Keywords: ASEAN-ChinaFree Trade Area; Cross-Border Electronic Public Services; Coordination

\section{Introduction}

With the establishment of ASEAN-China Free Trade Area in 2010, service trade has become one of the important parts of ACFTA Development. In order to promote the further development of bilateral trade, ASEAN and China have implemented e-Government which aims to deliver electronic public services for enterprises and citizens. E-Customs is a good example of electronic services. Since internal lack of effective coordination among those member countries and their local governments the and cooperation on customs, inspection, taxes and port management sector operations, most electronic public services do not work across borders or involve cumbersome procedures to be accessible. People from one ACFTA country cannot easily apply for public services in another country. This seriously reduces the mobility of businesses and citizens in ACFTA. The Members of ACFTA will work together to establish an efficient and convenient CBEPSP to simplify administrative procedures, improve administrative efficiency, and reduce administrative costs; Build ASEAN-China cooperation mechanism, reduce the difficulty of traditional enterprises to enter the cross-border trade, to facilitate trade and encourage the mobility of businesses and citizens, to push the economic integration between China and ASEAN countries.

\section{The Conception}

The electronic public services is government using the e-government application system to provide public service to enterprises, public business models, which is a new method different from the traditional public service (Li Lele, Lu Jingjun, 2010), whose aim is to improve the efficiency and quality of the government public service ability. Electronic services not only reduce travel costs by making procedures and forms available remotely, but they are in principle simpler, faster and more flexible. The basic pattern includes G2C, G2B and G2G. Through the electronic public service platform, the government can make a quick response to the demand for public services, and social organizations can also be more direct and extensive access to various services provided by the government. CBEPSP is the government members using platform to provide public e-Government services for the enterprises and citizens in ACFTA. Also support the 
third party agencies to provide e-Commerce, ePayment, e-Logistics,e-Transport,e-Identity,e-Health, e-Education and other services.

\section{Fundamental Function of Cross-Border Public Services Platform}

\subsection{Information Release}

Information release is a basic function of the service platform. On one hand, the platform could release the trade policy, economic trends, and economic development statistical data of the ASEAN members. On the other hand, the platform could push the personalize information to the enterprise, and without the need to search the information every month.

\subsection{Online Search of Information}

Through the online search system, the enterprises and citizens can search enough information what they need. Such as the cross-border trade related affairs, the agreement and the trade policy between the eleven members, the tax relief policy in different countries, provide the history information of the import and export, certificate of origin authentication.

\subsection{Business Management}

Clearance is the most complicated and important administrative matters in the cross-border trade. Through the online clearance system, networked enterprises can easily use the electronic authentication, online declaration for e-Customs clearance to submit the application through the electronic ledger, electronic card of certification of identity and other relevant documents. And through the electronic data between the departments, the enterprises reduce customs clearance costs; improve customs clearance efficiency, create a convenient environment and conditions for cross-border trade.

\subsection{Online Payment}

Using the third party payment platform, to provide cross-border payment service, which could provide a more safe and efficient online pay channels, to solve the cross-border trade online exchange issues and provide more facilitate customs clearance to the enterprise.

\subsection{Interaction}

This platform could facilitate diverse and humane ways of interaction between corporations and individual, such as email, online consulting, ecommerce, so that the communication is no longer subject to geographical restrictions, which could accelerate the flow of information among the ASEAN member countries.

\section{The services object of cross-border public services platform}

\subsection{Government Management}

CBEPSP could integrate the enterprise information, customs declaration and payment data. After scientific statistics and analysis, these data could provide effective supervision tool to the administrative departments, and provide scientific information to the governments and develop policy of cross-border services.

\subsection{Services for Businesses}

Businesses should be able to sell and provide services and products all across ACFTA through easy electronic public procurement. CBEPS make things very much easier for the operation of businesses (particularly SMEs). SMEs (enterprises with employees between 1-249 employees) account for the vast majority of enterprises in ACFTA. It is clear that SME businesses are at the heart of the economy, they are critical for economic growth in the near future. SMEs can be seen as the backbone of the economy, 
given the added value and employment they create. CBEPSP can stimulate, facilitate entrepreneurship and make it easier to do cross-border business for SMEs.

\subsection{Personal Mobility}

The function should ensure the development of interoperable services enabling citizens to communicate, perform transactions, and send and receive electronic documents and information to and from public administrations across the ACFTA. These will allow for delivering secure cross-border exchange and safe storage of electronic information (e-Delivery of documents and information). People shall be able to access personal documents such as health record from all over ACFTA, electronically enroll in any ACFTA university.

\section{Building cross-border public services platform}

\subsection{Portal Construction}

In Jan .2010, the ACFTA Business Portal (http://www.asean-cn.org) was officially opened which is responsible by the Chinese Ministry of Commerce. This website is the only official web portal which is approved by the Ministerial Statement of ASEAN-China Ministerial Economic Cooperation. The website aims at trading facilitation and removing the barriers that business face when wanting to offer their services and products abroad, and now it has already got the information dissemination functions in English. With the help of this portal, the ACFTA could take use of those applications, database construction and strengthening of business integration, and can make it to play an irreplaceable, an official websites of CBEPSP.

\subsection{Basic Database}

Powerful information database is a cornerstone to support the effective functioning ofthe CBEPSP.
With the development of database construction, informationresource gathering, processing, publishing and uniform technical standards and norms of management, this platform could effectively collate and collect the policy laws and regulations, tariff reductions and related statistical. Data and other information build a cross-border e-commerce database. Construction of the database will facilitate the integration and sharing of information, providing strong support for the online information search function, and providing the scientific basis for government decision-making and effective corporate management services.

\subsection{Business Integration}

Member States will fully utilize this cooperative mechanism to coordinate the clearance system, quality inspection system, taxation system, port management and other departments of business system from the other countries. They will get access to this platform by uniform standards and norms. Promote electronic data interchange and sharing, actively promote online reporting, online verification, online operations to improve administrative efficiency and to achieve cross-border service and trade related information sharing and collaboration, which could promote the establishment of China -ASEAN "one-stop" public service platform.

\subsection{Implementation Strategies}

The Member States will jointly share results in successful experiences gained in cross-border electronic public services to determine and agree on key cross-border services ready for sustainable implementation throughout ACFTA. Member States and the secretariats will assess their readiness by analyzing the organizational, legal, technical and semantic barriers that could hinder their definitive 
deployment. The availability of cross-border services in ACFTA will be increased, initially, through supporting new electronic public services based on well-defined needs, and on the opportunities for reuse of existing infrastructures. The envisaged actions should provide the prerequisites for the Member States to engage in full deployment throughout ACFTA of cross-border services and start new ones.

\section{Fundamentals of Cross-border Electronic} Platform for Public Service Functions

\subsection{Sound Policies and Regulations}

Existing policies and regulations are not sound enough which could be one of the most important reasons for the construction and development of restricting CBEPSP. Currently, ASEAN has not introduced electronic payment, electronic contracts, intellectual property, customs, cybercrime and consumer protection policies and regulations, and they are still lack of entities classified, business activities, operating income and other clear rules and guidance of cross-border trade in all import and export business aspects.

\subsection{Establish Credit System}

Compared to the domestic service and trade transactions, cross-border service and trade need to improve trans-regional, cross-cultural credit system so as to support their complex environment. Due to the difference of national laws, they are lack of a unified credit mark. Therefore, the national credit management system is still not well applied to crossborder service and trade. Cross-border service and trade credit system require coordination of the governments from all the countries and relevant organizations to develop industry standards, to improve the certification system, and to seek the legal framework of credit institutional arrangements and to establishment a reliable trading environment.

\subsection{Unify Data-exchanging Standards}

On the basis of existing international standards, establishing and improving the standard system of cross-border trade and the cross-border product barcode standards, unifying the data-exchanging standards among the member states, and promoting the cross-border e-logistics barcode standardization.

\subsection{Build Management Institution}

Build operation management center of CBEPSP and which is responsible for the operation and maintenance of software and hardware. Building liaison institution and liaisons is assigned from countries for the operation of oversee platform and releasing of policy news after review. Building customer-service network which covers the ACFTA countries and the network provides after-sale service, prevents from cheating, resolves disputes and ensures legitimate rights of enterprises and consumers.

\subsection{Establish Coordination Mechanism}

Through the Economic Working Group of ASEANChina Joint Cooperation Committee and the ASEAN Secretariat, strengthening communication and trust among ASEAN members, establishing long-term coordination mechanism likecustomer protection and rights, online dispute resolution, information exchange and sharing.

\subsection{Strengthen Information Security}

Conduct personal data protection including consumer data, privacy and trade. Guarantee the truth and completeness of enterprise information. Ensure the traceability and payment security of each transaction through relevant technical support. The identity of users and enterprises can be accurately recognized. Then continuously improve the security of service. 


\section{References}

(1) Ales, Groznik, Peter Trkman. (2009). Upstream supply chain management in e-government:The case of Slovenia[J].Government Information Quarterly

(2) Chuanjun, Li. (2010). Electronic public service:The direction of the development of egovernment $[\mathrm{J}]$ Administration Reform

(3) European Union. (2014). Helping Europe Move Towards a Digital Single market[S/OL]. http://ec.europa.eu/isa/policy/index_en.htm,3-20
(4) European Union ISA. (2014). Programme for Targeted Action [S/OL]. http://ec.europa.eu/isa/policy/policy 3_en.htm,3-20

(5) Lilele,Lu Jingjun. (2010). Research on Current Situation and Strategies of electronic public services in China[J]. Egovernment

(6) Ministry of Commerce of China:China and ASEAN Signed the Service Trade Agreement.(2007). [N/OL]. http://english.mofcom.gov.cn/aarticle/newsrelease/sig nificantnews/200701/20070104272435.html,2014:3-

20. 